\title{
MODELLING AND SIMULATION OF FREE-FLOWING MATERIAL WEIGHING IN WEIGH HOPPER
}

\author{
Khobin V.A. ${ }^{1}$, Dets D.V. ${ }^{2}$, Levinskyi M.V. ${ }^{3}$, Levinskyi V.M. ${ }^{4}$ \\ 1,2,3,4 Odessa National Academy of Food Technologies \\ ORCID: ${ }^{1} 0000-0003-0238-8371,{ }^{2} 0000-0002-8556-5451,{ }^{3} 0000-0002-6544-5110,{ }^{4} 0000-0002-3563-528 X$ \\ E-mail: ․khobin@onaft.edu.ua, ${ }^{2}$ dec@onaft.edu.ua, ${ }^{3}$ MaxLevinskyi@gmail.com, ${ }^{4}$ ValeryLevinskyi@gmail.com
}

Copyright (C) 2018 by author and the journal "Automation technologies and business - processes.

This work is licensed under the Creative Commons Attribution International License (CC BY).

http://creativecommons.org/licanses/by/4.0

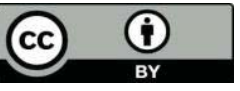

ONAFT

Open Access

DOI:

\section{Abstract.}

Topicality. Necessity of reducing ships' downtime during grain transshipment from port elevators requires intensification of handling operations. It can be provided not only by using transport mechanisms of greater capacity, but also by threadtransport lines operations automation, which will eliminate possible human operator errors. Creation of automatic control systems, in turn, requires development of mathematical and simulation models of thread-transport lines, an integral part of which are weigh hoppers of periodic action.

Objective. To create simulation model of weigh hopper operation, which reflects its properties as a control object.

Method. Known differential and algebraic equations of weighing in weigh hopper are used. They include influence grain weight on its mechanical system as well as dynamic force which grain creates during falling. Simulation models for MatLab/Simulink were created on the basis of these equations.

Results. Computer experiments with weigh hopper models which include simulation of different operating conditions were planned and carried out. Trends were obtained, which define effectiveness of its operation.

Conclusions. Effectiveness of weighing process is defined by optimal combination of weigh hopper productivity and its dynamic inaccuracy. To increase productivity weighing cycle must be reduced. However, this reduction is limited by time, which is necessary for damping of mechanical system oscillations.

\section{Анотація.}

Актуальність. Необхідність скорочення простоїв судів при перевалиі на них зерна із припортових елеваторів вимагає інтенсифікації вантажно-розвантажувальних робіт. Вона може бути забезпечена не тільки за рахунок використання транспортних механізмів більшої продуктивності, але й за рахунок автоматизацї роботи поточнотранспортних ліній, щчо дозволить виключити можливі помилки людини-оператора. Створення систем автоматичного керування, у свою чергу, вимагає розробки математичних $i$ імітаційних моделей поточнотранспортних ліній, невід'ємною частиною яких є бункерні ваги періодичної дї.

Мета. Створити імітаційну модель функціонування ваг, яка відбиває їхні властивості як об'єкта керування.

Метод. Використані відомі диференціальні та алгебраӥчні рівняння зважування у ваговому бункері, які враховують вплив на його механічну систему не тільки ваги зерна, але і силу, яку воно створює при падінні. На базі ичих рівнянь створені імітаційні моделі в середовищі Simulink/Matlab.

Результати. Сплановані і проведені комп'ютерні експерименти з моделями ваг при імітації різних умов функиіонування. Отримані графіки, які характеризують ефективність їх роботи.

Висновки. Ефективність зважування визначається оптимальним співвіднотенням продуктивності ваг $i$ їх динамічної похибки. Збільшення продуктивності вимагає скорочення ияиклу зважування. Однак изе скорочення обмежується часом, необхідни для загасання коливань механічної системи.

Keywords: weigh hopper of periodic operation, simulation model.

\section{Nomenclature}

$C$ - dampening coefficient;

$d(t), \Delta t$ - time increments;

$d_{g}$ - grain volume density;
$M_{w h}(t)$ - total weight of weigh hopper;

$M_{t r}(t)$ - weight of empty hopper;

$M_{g f}(t)$ - actual grain weight; 
$F_{w h}(t)$ - force, acting upon weigh hopper;

$F_{s}(t)$ - static component of $F_{w h}(t)$,

$F_{d}(t)$ - dynamic component of $F_{w h}(t)$,

$g$ - free fall acceleration;

$H$ - rigidity of measuring cell;

$L_{w h}$ - height of weigh hopper;

\section{Introduction}

At present time in Ukraine intensive construction of new and reconstruction of old harbor grain elevators are taking place, which is caused by increasing volume of cereal crop export. To reduce downtime of ships and railway trains during grain transshipment enterprises are equipped with transport mechanisms - conveyors, bucket elevators with high output of up to 1000 tones per hour and higher. This predetermines necessity of perfecting thread-transport lines automatic control algorithms, because possible human operator errors cause great downtimes, and, therefore, economic losses.

Complexity in development of such algorithms is determined by next main factors:

- significant transport delay in transmission of control impacts during stabilization of grain flow rate;

- changing of dynamic properties of transport mechanisms, as control objects;

- different productivity of transport mechanisms, included in one route;

- presence in route of periodic operation mechanisms, for example, weigh hoppers.

By significant degree these complexities were overcame with created algorithms [1, 2], which stipulate for automatic control of loading thread-transport lines without human operator interference.

These technologies demanded development of detailed dynamic models of conveyors, bucket elevators, control gate valves and their driving electric motors. Development of mathematical and simulation models of periodic operation weigh hoppers, which are integral part of grain transshipment systems, remain problem of current importance.

\section{Problem statement}

Simplified weigh hopper structure is presented in fig. 1. Structure contains: upper garner B1 and lower garner B3, which are connected to weigh hopper hull, as well weigh hopper B2 itself, which rest upon measuring cells, deformation of which allows to determine loaded grain portion weight.

Garners B1, B3 and weigh hopper B2 are equipped with level sensors. Their signals are used in automatic control system to control position of the sliding gate valves S1, S2, S3. This provides transfer of grain portions from up to down.

For generality, construction version, in which B2 weight is compensated by counterbalances. In this case dynamic measuring range is widened and, therefore, accuracy increases. meigh hopper;

$V_{s t}(t)$ - initial grain velocity;

$V_{f n}(t)$ - finite grain velocity;
$M_{g m}(t)$ - measured grain weight;

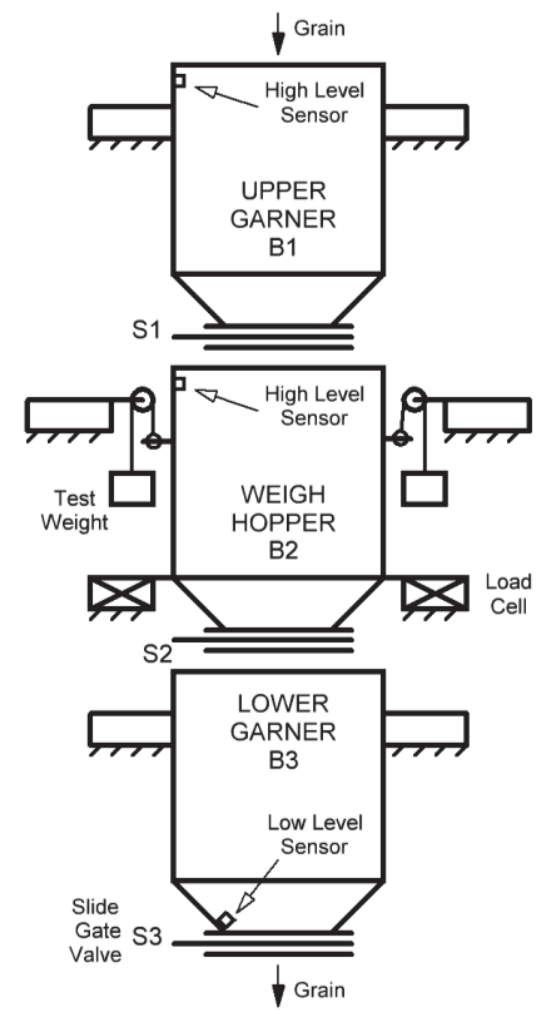

Fig. 1 - Main components of weigh hopper structure 
Detailed mathematical models of weighing in weigh hopper are presented in [3]. In particular, bunker mass weigh model includes models of weigh hopper mechanical system equilibrium and decoding its dislocation in measured weight:

$$
\begin{gathered}
\left(M_{w h}+2 M_{t w}\right)^{d^{2} S_{r}(t) / t^{2}+C} C^{d S_{r}(t)} / d t+H \cdot S_{r}(t)=T_{d} F_{w h}(t) / d t+F_{w h}(t), \\
M_{g m}(t)=H \cdot S_{r}(t) / g .
\end{gathered}
$$

In the process of filling weigh hopper with grain its mass substantially increases:

Force $F_{w h}(t)$, which impacts hopper, consists of two parts:

$$
M_{w h}(t)=M_{t r}+M_{g f}(t)
$$

a) static $F_{s}(t)$ - this is grain weight in hopper, since weight of empty hopper is compensated by counterweights:

$$
F_{s}(t)=M_{g f}(t) \cdot g=g \int_{0}^{t} Q_{g f}(t) d t
$$

b) dynamic $F_{d}(t)$, which is caused by grain falling.

Let's examine mathematical models $F_{d}(t)$. In a brief space of time $d t$ grain portion with mass $Q_{g f}(t) \cdot d t$ enters weigh hopper and under the influence of terrestrial attraction constant force is created $Q_{g f}(t) \cdot d t \cdot g$, which accelerates falling of this portion. Impulse of this force, taking into account time of its action, to put it more precisely, portion falling time span $\Delta t$, is equal $Q_{g f}(t) \cdot d t \cdot g \cdot \Delta t$. If we assume grain portion as a material point, which will commit non-elastic blow to the bottom of weigh hopper in during $d t$, then weigh hopper is impacted by force:

$$
F_{d}(t)=Q_{g f}(t) \cdot d t \cdot g \cdot \Delta t /_{d t}=Q_{g f}(t) \cdot g \cdot \Delta t
$$

Since force $Q_{g f}(t) \cdot d t \cdot g$ is constant, then its impulse is equal to impulse of mass [4]. Then (5) can be presented as:

$$
F_{d}(t)=M_{g f}(t) \cdot \Delta V /_{d t}=Q_{g f}(t) \cdot d t \cdot \Delta V / /_{d t}=Q_{g f}(t) \cdot \Delta V
$$

It should be noted that even with constant grain flow rate $Q_{g f}(t)=$ const, dynamic component $F_{d}(t)$ will gradually decrease as weigh hopper is filling, since falling time is decreasing $\Delta t$ and difference $\Delta V$ between initial $V_{s t}(t)$ and finite $V_{f n}(t)$ falling velocity.

During weighing of all portions, except first one, velocity $V_{s t}(0) \approx 0$, since grain movement begins in upper garner. Finite velocity $V_{f n}(t)$ can be calculated, based upon known values of grain volumetric density $d_{g}$, height $L_{w h}$ and area $S_{w h}$ of weigh hopper's bottom:

$$
V_{f n}(t)=\sqrt{2 g\left(L_{w h}-\frac{1}{s_{w h}} \int_{0}^{t} \frac{Q_{g f}(t)}{d_{g}} d t\right)} .
$$

\section{Literature overview}

Weigh hopper with high productivity is described in [5,6]. Counterweights are not used in its construction. Automatic control algorithms provide for weighing of full bunker with grain initially, and then weighing of empty bunker after its discharge. At that weight measuring begins with some lag from the moment of bunker filling with grain and from the moment of its discharge. Thus mechanical system oscillations impact on measuring accuracy is compensated.

Calculation method of theoretically possible maximum accuracy of serially produced continuous operation weight batchers dosing is presented in [7].

Mathematical model of discrete weight batcher, considering bulk solids flow percussive impact on it, is researched in [8]. Recommendations were made for dosing effectiveness increase due to optimal combination of productivity and batcher dynamic error.

\section{Materials and methods}

Based on dependences (1 - 7) weigh hopper mathematical model was developed in MatLab/Simulink environment. (see fig. 2). It includes sliding gate valves models S1, S2, S3, known from [9], garner models B1, B2, B3, as well as models of equilibrium and decoding. 


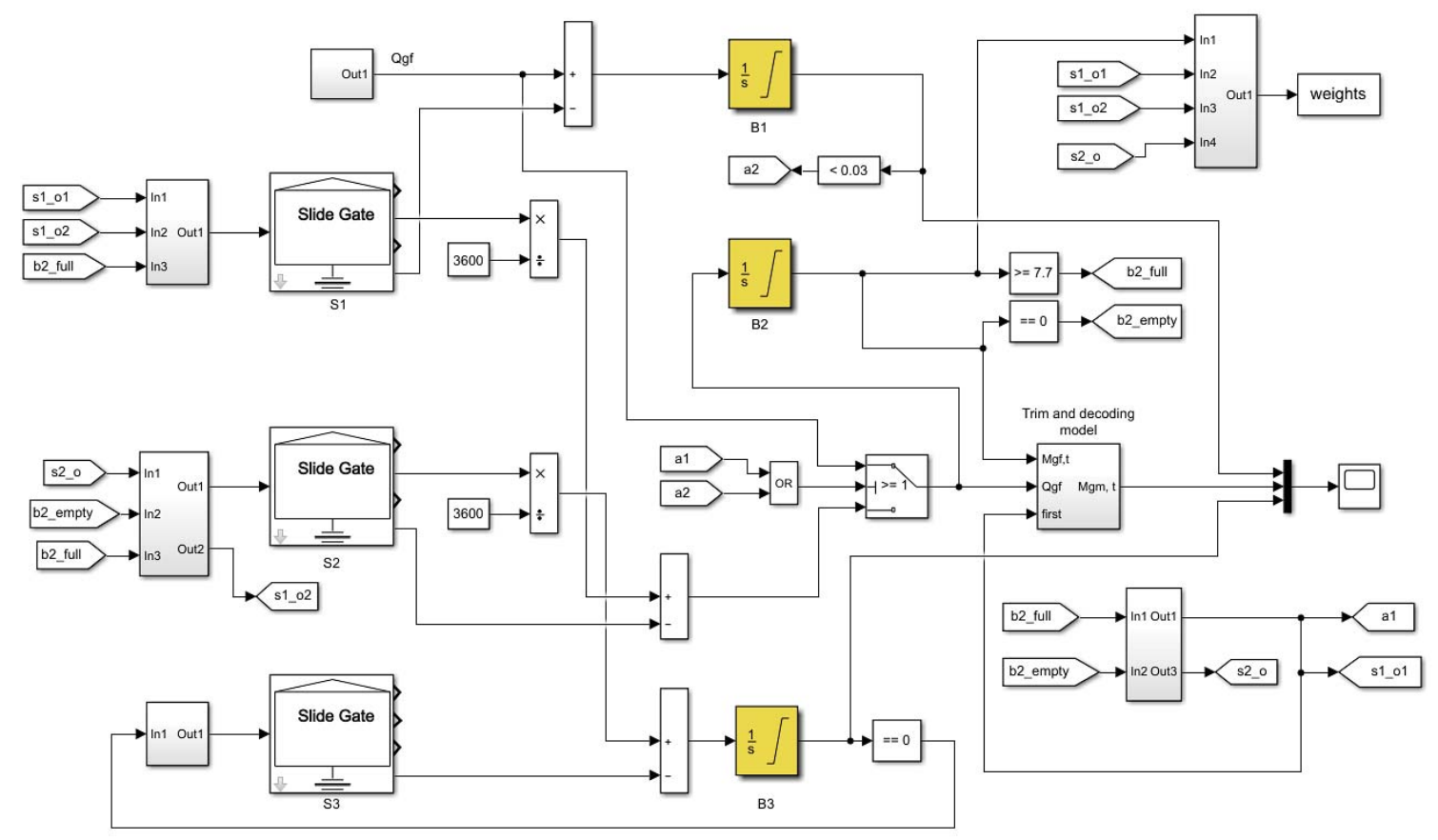

Fig. 2 - Weigh hopper simulation model

The rest of the simulation model blocks implement gate valves logical control functions during measuring the first portion of grain weight and the next ones. Initial grain flow rate $Q_{g f}(t)$ when entering weigh hopper is determined by equipment placed before it.

Weigh hopper mechanical system equilibrium and decoding models make calculations based upon dependences $(1-6)$.

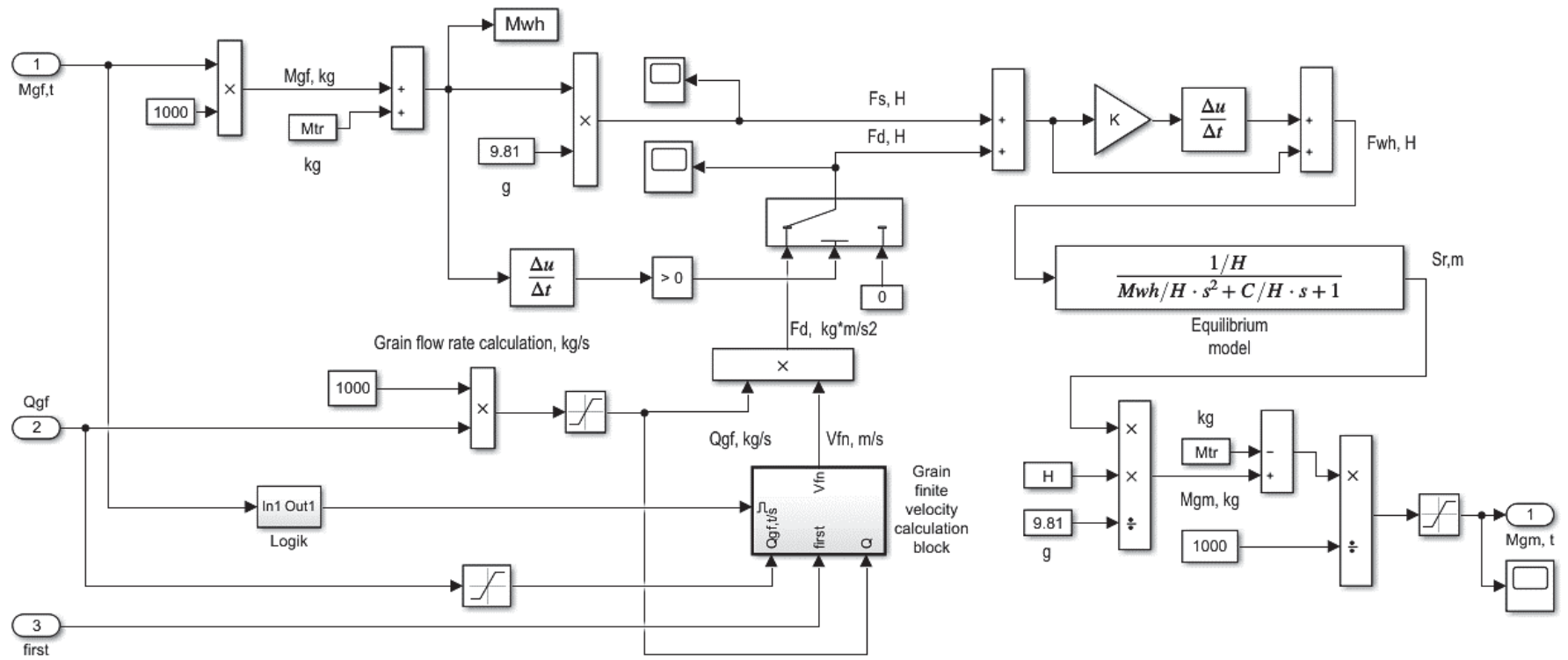

Fig. 3 - Weigh hopper mechanical system and decoding models

Grain falling finite velocity estimation block model (fig. 4) calculates $V_{f n}(t)$ using dependence (7) with known values of weigh hopper geometric dimensions. 


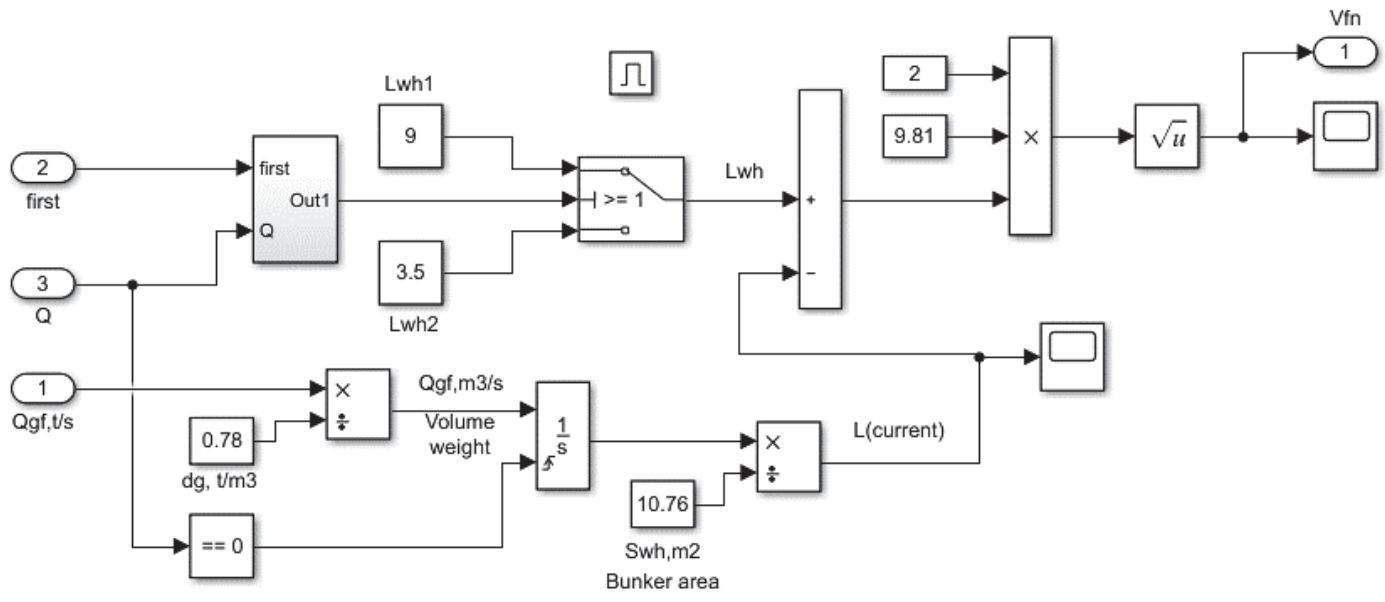

Fig. 4 - Grain falling finite velocity estimation block model

The fact that, during measuring initial grain portion, sliding gate valve of upper garner is open and grain is falling to the bottom of weigh hopper from high height is taken into account in this model.

\section{Experiments and results}

Modelling results fragments (fig. 5) illustrate normal functioning mode of weigh hopper, without overfilling of upper B1 or lower B3 garners. Pause between the moment of sliding gate valve S1 closes and the moment of sliding gate valve S2 opens is sufficient for damping the oscillations of weigh hopper mechanical system, which lowers the dynamic component of measuring error.
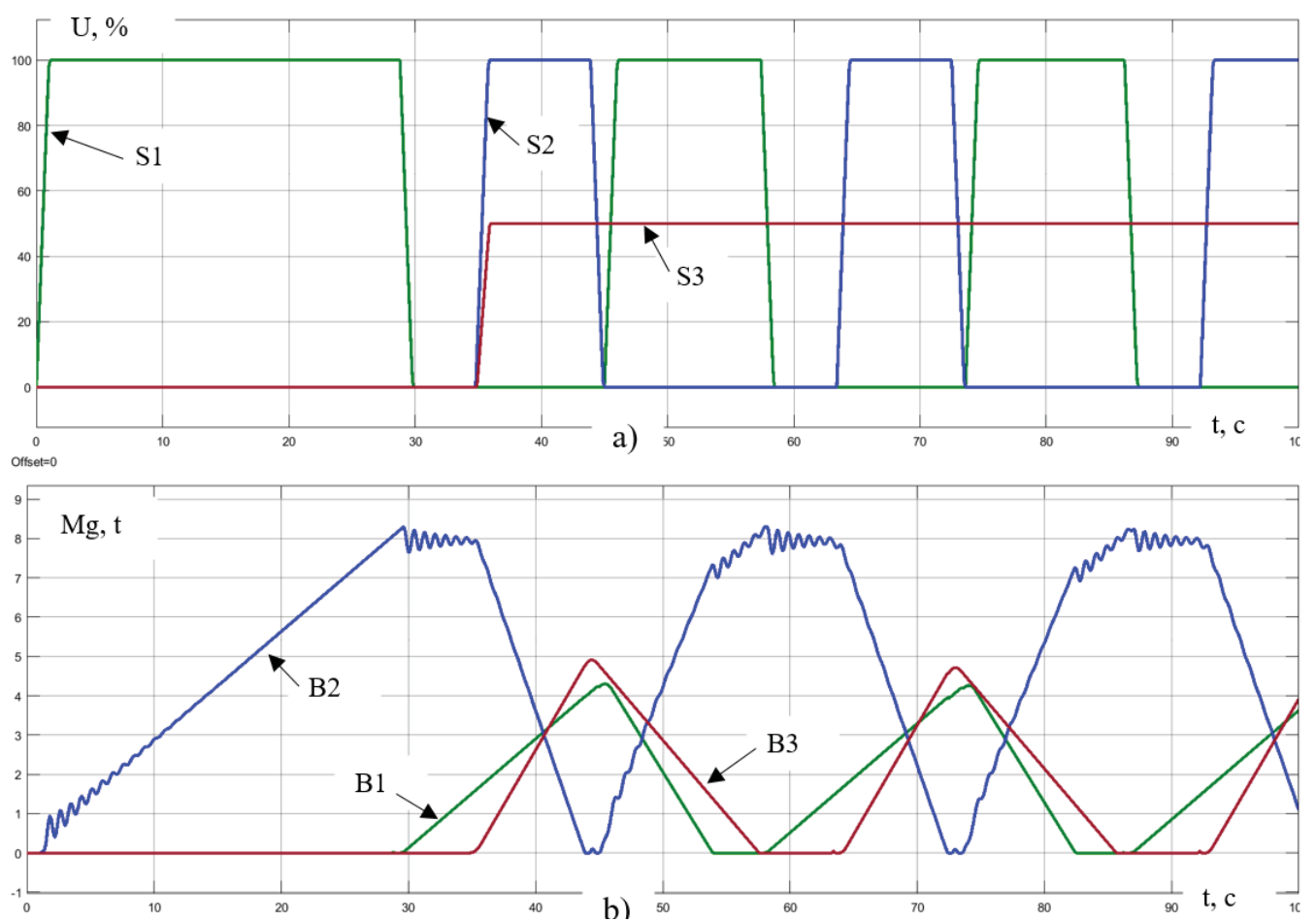

Fig. 5 - Weigh hopper normal functioning mode simulation fragments with constant input flow rate $Q_{g f}=1000$ tones per hour:

a) alteration of sliding gate valves $S 1, S 2, S 3$ position $0 . . .100 \%$; b) alteration of grain mass in garners $B 1, B 2, B 3$

When increasing input grain flow rate $Q_{g f}$ or changing the position of sliding gate valve S3, emergency or pre-emergency modes of weigh hopper operation can be modeled. 


\section{Conclusions}

Effectiveness of weighing process is defined by optimal combination of weigh hopper productivity and its dynamic error. Productivity increase demand shortening of time needed for weighing process. However, this shortening is limited by time needed for damping of mechanical system oscillations.

Proposed weigh hopper models allow simulation modelling of normal and emergency modes of operation. They can be used in general structures of thread-transport lines models.

\section{References}

[1] "Sposib avtomatychnoho upravlinnia zavantazhenniam potokovo-transportnoi linii sypkykh materialiv", $95887,2011$.

[2] "Sposib avtomatychnoho upravlinnia potokovo-transportnoiu liniieiu sypkykh materialiv", 98736, 2012.

[3] V. Khobyn and D. Dets, "Ymytatsyonnaia matematycheskaia model mnohokomponentnoho vesovoho dozatora peryodycheskoho deistvyia", Naukovi pratsi ONAKHT, vol. 2, pp. 171-177, 2002.

[4] K. Kuhling, Spravochnyk po fyzyke. Moscow: Myr, 1985, p. 520.

[5] "Bulk Weighers GSI", Bulk Weighers, 2019. [Online]. Available: http://www.grainsystems.com/products/materialhandling/bulk-weighers.html. [Accessed: 06- Apr- 2019].

[6] "Hopper scale - Automatic bulk scales - Precia Molen", Precia Molen, 2019. [Online]. Available: https://www.preciamolen.com/range/automatic-bulk-scales. [Accessed: 06- Apr- 2019].

[7] S. Pershina and A. Katalimov, Vesovoe dozyrovanye zernystikh materyalov. Moscow: Mashinostroenie, 2009 , p. 260.

[8] S. Efremov and Y. Vasilkov, "Ydentyfykatsyia modely peryodycheskoho dozatora v realnom vremeny", in Matematycheskye metodi v khymyy y khymycheskoi tekhnolohyy, 1995, p. 21.

[9] Kyriazov and V. Khobyn, "Prohrammno-tekhnycheskyi kompleks dlia otladky prykladnoho PO avtomatyzyrovannoi systemi optymyzatsyy zahruzky PTL sipuchymy materyalamy", Avtomatyzatsiia tekhnolohichnykh ta biznes-protsesiv, vol. 6, no. 4, pp. 29-42, 2014.

\section{Список використаних джерел}

[1] Спосіб автоматичного управління завантаженням потоково-транспортної лінії сипких матеріалів: пат. на винахід 95887 Україна: МПК (2011.01), B65G 17/00, B65G47/46 (2006.01), B65G65/42 (2006.01), G01G 11/12 (2006.01).№ а201015861; заявл. 29.12.10; опубл. 12.09.11, Бюл. № 17.

[2] Спосіб автоматичного управління потоково-транспортною лінією сипких матеріалів: пат. на винахід 98736 Україна: МПК (2012.01) B65G 17/00, B65G 47/00, B65G 43/00, Н02H5/04 (2006.01). № а201105403; заявл. 27.04.11; опубл. 11.06.12, Бюл. № 11.

[3] Хобин В.А., Дец Д.В. Имитационная математическая модель многокомпонентного весового дозатора периодического действия. Наукові праці ОНАХТ. 2002. №2. С. 171 -177.

[4] Кухлинг Х. Справочник по физике / перевод с немецкого. М.: Мир, 1985. 520 с.

[5] URL: http://www.grainsystems.com/products/material-handling/bulk-weighers.html (дата звернення 27.03.2019)

[6] URL:https://www.preciamolen.com/range/automatic-bulk-scales/ (дата звернення 27.03.2019)

[7] Весовое дозирование зернистых материалов / ПершинаС.В., КаталымовА.В., ОднолькоВ.Г., ПершинВ.Ф. М.: Машиностроение, 2009. 260 с.

[8] Ефремов С.А., Васильков Ю.В., Ершов О.Г., Работнов И.В. Идентификация модели периодического дозатора в реальном времени. Математические методы в химии и химической технологии: материалы международной конференции. Тверь: ТГТУ, 1995. С.21.

[9] Кирьязов И.Н., Хобин В.А. Программно-технический комплекс для отладки прикладного ПО автоматизированной системы оптимизации загрузки ПТЛ сыпучими материалами. Автоматизація технологічних та бізнес-процесів. Одеса, 2014. № 4. Т. 6. С. 29-42. 